
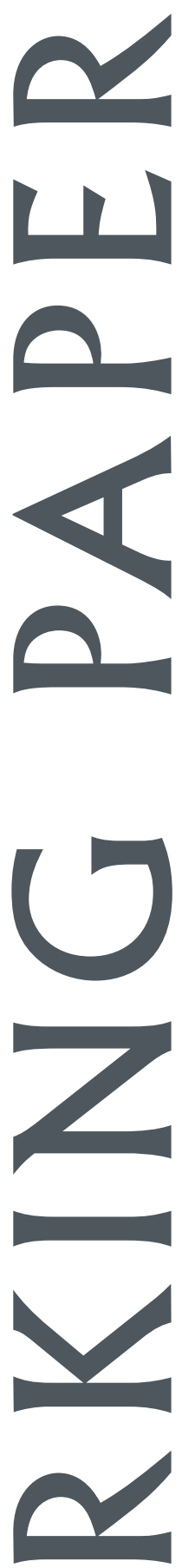

EAST-WEST CENTER 
The U.S. Congress established the East-West Center in 1960 to foster mutual understanding and cooperation among the governments and peoples of the Asia Pacific region including the United States. Funding for the Center comes from the U.S. government with additional support provided by private agencies, individuals, corporations, and Asian and Pacific governments.

East-West Center Working Papers are circulated for comment and to inform interested colleagues about work in progress at the Center.

For more information about the Center or to order publications, contact:

Publication Sales Office

East-West Center

1601 East-West Road

Honolulu, Hawaii 96848-1601

Telephone: 808-944-7145

Facsimile: 808-944-7376

Email: ewcbooks@EastWestCenter.org

Website: www.EastWestCenter.org 


\title{
Searching for a New Role in East Asian Regionalization: Japanese Production Networks in the Electronics Industry
}

\author{
Dieter Ernst
}

Dieter Ernst is a Senior Fellow and Theme Leader for Economic Studies at the East-West Center. His previous affiliations include the OECD, Paris, as senior advisor, and the Berkeley Roundtable on the International Economy (BRIE), at the University of California at Berkeley as research director. Dr. Ernst co-chairs an advisory committee for the U.S. Social Science Research Council (SSRC) to develop a new program on Asia. He has served on the Committee on Information Technology and International Cooperation (ITIC) of the SSRC. He also serves as advisor to the Committee established by the Prime Minister's Science Advisor to set up a National Science Foundation for Malaysia. Recent books include International Production Networks in Asia: Rivalry or Riches?, and Technological Capabilities and Export Success: Lessons from East Asia.

This paper will be published in Peter and J. Katzenstein and Takashi Shiraishi, eds., Remaking East Asia: Beyond Americanization and Japanization, Cornell University Press.

East-West Center Working Papers: Economics Series reports on research in progress. This paper has been peer-reviewed. The views expressed are those of the author and not necessarily those of the Center. Please direct orders and requests to the East-West Center's Publication Sales Office. The price for Working Papers is $\$ 3.00$ each plus shipping and handling. 


\section{Searching for a New Role in East Asian Regionalization - Japanese Production Networks in the Electronics Industry ${ }^{1}$}

by

\section{Dieter Ernst}

The electronics industry has been a trailblazer and test bed for East Asian regionalization. Japanese firms have been a major source of capital, components and machinery, as well as business models and management techniques. However, in response to a persistent recession in this industry, the cards are now being reshuffled, giving rise to far-reaching adjustments in the region's trade and investment patterns, and in the development trajectories of its electronics industries. The traditional "flying geese" model of economic interactions between Japan and East Asia has clearly come to an end as a unifying force of regionalization (Ozawa, 2003; METI, 2003). But what new forces will shape East Asia’s future regional development patterns?

Since the 1990s, American corporations have consolidated their leadership in semiconductors and computers, creating new product, software and service markets, e.g. the Internet, e-business, advanced microprocessors, and operating systems for an increasing variety of digital devices (Ernst, 2002a). Japanese electronics firms, on the other hand, have experienced a rapid erosion of their erstwhile leadership in consumer electronics and semiconductors, and they have failed to catch up with US industry leaders in the above new product, software and service markets. The electronics industry thus appears to support the assessment of Stephen Roach (chief economist of Morgan Stanley) that "the world is more US-centric now than it has ever been" (Roach, 2003).

But does this imply that East Asia's electronics industry will be "Americanized"? And which role will Japanese firms play in this game? This chapter analyzes one side of the equation. I explore how Japanese electronics firms are searching for new ways to transform their East Asian production networks (EAPNs) to cope with the new opportunities and challenges of a radically transformed East Asian regional economy. I document that, far from withdrawing from East 
Asia, Japanese corporate capital in the electronics industry now critically depends on the region, not only as a global export production base, but also as a major and increasingly sophisticated market for its products, services and technology, and as a source of lower-cost knowledge workers. ${ }^{2}$ To benefit from the growing importance of East Asia, Japanese electronics firms are searching for ways to expand and upgrade their regional production networks, with a particular focus on China.

The analytical challenge is to explain why Japanese firms are finding it difficult to make the necessary adjustments in the organization and management of their regional production networks. Accumulated weaknesses of the Japanese business model provide part of the explanation. However, equally important exogenous forces are at work. A central proposition of the chapter is that competition between distinct national business models is no longer the dominant determinant of East Asian regionalization. The dichotomy: "Americanization versus Japanization" that has shaped the earlier literature is insufficient to capture what is really happening.

More important are fundamental transformations in the organization of international business that are especially pronounced in the electronics industry (Ernst, 2003a): firms of diverse nationality compete and collaborate within multi-layered global "networks of networks" of marketing, production and innovation. This has forced Japanese firms into dense interaction with a multitude of firms from the US as well as from East Asia's leading electronics exporting countries. Another critical exogenous force has been the rise of China as a global export production base, as a sophisticated growth market, especially for mobile communications and digital consumer devices, and as a new source of R\&D and innovation (Ernst, forthcoming). Both forces combine to produce increasingly complex processes of regionalization. Economic interactions within the region, such as trade, investment and competitive strategies, have moved beyond a "short causal" chain, where causes and effects are easy to disentangle, and where it is 
possible to name names and to develop effective responses. ${ }^{3}$ Identifying, monitoring, let alone "controlling" the transformational actors and mechanisms by nationality has become much more tricky.

Part 1 introduces a few conceptual building-blocks that we need to capture the interactions between international business organization and regionalization. Part 2 describes the growing dependence of Japan's electronics industry on Asia, and explores how Japanese electronics firms are searching for ways to expand and upgrade their regional production networks, with China as the main prize. Part 3 examines constraints to change. I highlight peculiar features of the Japanese network management model in East Asia that once may have reflected strength. But now these very same features have turned into systemic weaknesses, as they constrain the capacity of Japanese firms to cope with and shape East Asia's increasingly complex processes of regionalization. The chapter concludes with an illustrative example of how some Japanese electronics firms are seeking to turn around gradually their EAPNs, by developing strategic alliances with emerging new industry leaders in Asia, primarily from Greater China.

\section{Global Production Networks and Regionalization}

"Regionalization" can be defined as the integration, across national borders, but within a macro-region, of markets for goods, capital, services, knowledge, and labor. Barriers to integration continue to exist of course in different markets (especially for low-wage labor), so integration is far from perfect. But there is no doubt that a massive integration has taken place across East Asian borders that, only a short while ago, seemed to be impenetrable (Ng and Yeats, 2003). This raises the question: Who are the "integrators"?

Research on East Asian regionalization has argued that, while states obviously play an important role in reshaping institutions and regulations, the dominant integrators have been corporations. Much of the literature has focused on the battle between "Japanization" and 
"Americanization" as the main drivers of regionalization. But there is little agreement on the precise features of business organization that differentiate the comparative capacities of Japanese and American firms to shape regionalization.

Unfortunately, there is very little theoretical work on this relationship: we still lack a unified theory of regionalization and international business organization. However, we can build on research that links theories of trade and FDI and theories of global production networks. ${ }^{4}$ This research shows that corporate strategies, organization and investment decisions shape trade patterns and the spatial division of labor of economic activities, as well as transfer of technology and knowledge diffusion (Ernst and Guerrieri, 1998). Corporations may also indirectly affect regionalization by lobbying states to change institutions and regulations. The driving force is competition (Ernst, 2002a). In knowledge-intensive industries like electronics, intense price competition needs to be combined with product differentiation, in a situation where continuous price wars erode profit margins. Of critical importance, however, is speed-to-market: getting the right product to the largest volume segment of the market right on time can provide huge profits. Being late can be a disaster, and may even drive a firm out of business. The result has been an increasing uncertainty and volatility, and a destabilization of established market leadership positions

No firm, not even a dominant market leader, can generate all the different capabilities internally that are necessary to cope with the requirements of global competition. Competitive success thus critically depends on "vertical specialization": a capacity to selectively source specialized capabilities outside the firm that can range from simple contract assembly to quite sophisticated design capabilities. This requires a shift from individual to increasingly collective forms of organization, from the multidivisional (M-form) functional hierarchy (Chandler, 1977) of "multinational corporations" to the networked global flagship model. Trade economists have recently discovered the importance of changes in the organization of international production as 
a determinant of trade patterns (for example, Feenstra, 1998; Cheng and Kierzkowski, 2001). Their work demonstrates that (i) production is increasingly 'fragmented', with parts of the production process being scattered across a number of countries, hence increasing the share of trade in parts and components; (ii) that there is reintegration through global production networks (GPNs); and (iii) that countries and regions which have been able to become a part of these network are the ones which have industrialized the fastest.

This chapter builds on this work, but uses a broader concept that emphasizes four characteristics of GPNs that influence regionalization (Ernst, 2003b, 2002b, 1997): i) scope: GPNs encompass all stages of the value chain, not just production, but also sales, procurement, outsourcing, and R\&D; ii) asymmetry: flagships dominate control over network resources and decision-making; iii) knowledge diffusion: the sharing of knowledge is the necessary glue that keeps these networks growing (Ernst and Kim, 2002); and iv) information systems: the increasing use of digital information systems to manage these networks enhances not only information exchange, but also provides new opportunities for the sharing and joint creation of knowledge.

A Japanese Asian production network covers both intra-firm and inter-firm transactions and forms of coordination: it links together the flagship's own subsidiaries, affiliates and joint ventures with its subcontractors, suppliers, service providers, as well as partners in strategic alliances. A network flagship like Hitachi or Sony breaks down the value chain into a variety of discrete functions and locates them wherever they can be carried out most effectively, where they improve the firm's access to resources, capabilities and knowledge, and where they are needed to facilitate the penetration of important growth markets. It is important to emphasize that the chain of causation appears to work both ways: changes in the organization of Japanese EAPNs have led to changes in East Asia's trade patterns and investment allocation; those changes in turn give rise to further changes in the organization of the above networks. 


\section{Expanding and Upgrading Links with East Asia}

Japan has experienced a long-term decline in its share in global trade and FDI during the 1990s, the country's "lost decade". Its share in global exports fell to $7.6 \%$ in 2000 , after peaking at $10.2 \%$ in 1986 (JETRO, 2002: fig. V-3). In 1992, Japan's outward FDI stock was $12.4 \%$ of the world total, second only to the US, but by 2000 it had fallen back to eighth, the same position it had occupied in $1980 .{ }^{5}$ Moreover, after being the world's largest source of outward FDI flows in 1990, Japan dropped to seventh place in 2001.

Yet, since the turn of the century, a reversal of Japan's declining global presence has occurred, primarily driven by an expansion of trade and investment links with East Asia. From a peak of almost $22 \%$ in fy 1997 , the overseas production ratio (OPR) ${ }^{6}$ of Japanese manufacturing firms had declined until fy 1999 . Since then, there has been a steady increase to more than $24 \%$ in fy 2001, with projections of an increase to almost 32\% in fy 2005 (JBICI, 2003: 13). The electronics industry leads, with an estimated OPR in fy 2002 of almost $41 \%$, up from $38 \%$ one year earlier. East Asia is the main destination of this expansion of overseas operations of Japanese corporate capital in the electronics industry. I will describe the growing dependence of Japan's electronics industry on Asia, and explore how Japanese electronics firms are searching for ways to expand and upgrade their regional production networks, with a particular focus on China.

\subsection{Growing Dependence on East Asia}

Japan's electronics industry critically depends on East Asia. Over time, this dependency has deepened, and it also has become much more complex and multi-faceted. Of primary importance has been the region's role as a global export production platform. Since the catalytic shock of the 1985 Plaza agreement, when the Yen appreciation inflated Japan's production costs, Japanese 
firms have relocated manufacturing to lower-labor-cost locations in Asia, first in Korea, Taiwan, Hong Kong, and Singapore, then in Malaysia, Thailand, Indonesia and the Philippines. China's role as Japan's global low-cost export platform production base has substantially increased over the last decade. In fy 2002, almost two thirds of the overseas manufacturing bases of Japanese manufacturing firms that have responded to the JBIC surveys were concentrated in East Asia, up from $60 \%$ in fy $2000 \mathrm{~b}(\mathrm{JBICI}, 2003){ }^{7}$

Initially, the focus has been on consumer electronics and home appliances, as well as related components. Yet, over the last few years, there has been a substantial diversification in the product mix that Japanese firms produce in Asia, to include both hardware and software required for computing, communication and industrial applications. At the same time, increasingly complex stages of production and overall supply chain management have gradually been relocated from Japan to Asian locations. This upgrading is a response to the intensifying competition that Japanese electronics firms face both from above and from below.

From above, American electronics industry leaders have raced ahead in the most prized areas of technological innovation, as far as these can be measured by patent statistics. The US "innovation score" has more than doubled from 41 (in 1985) to almost 101 (in 2002), a rate far better than for any other country ${ }^{8}$ (CHI/MIT 2003). In 2002, all 15 leading companies with the best record on patent citations were based in the US, with nine of them in the electronics industry. Japan has maintained its second place, with an increase in its "innovation score" from 15 to 33, but it is now further trailing behind the US. And European industry leaders both in telecommunications and in consumer electronics have strengthened their market position by aggressively partnering with Asian companies, especially from China.

From below, Japanese electronics firms are facing new competitors from six Asian countries (China, Korea, Taiwan, Singapore, Malaysia and India) that have emerged as the new center of gravity in global electronics exports (Ernst, 2004a). China has now become the third largest 
exporter of electronics products (up from 10 ${ }^{\text {th }}$ in 2000), and the second largest importer (up from $7^{\text {th }}$ in 2000). Taiwan ranks as the $\# 1$ global world market supplier for 14 electronics products. This includes silicon foundry services (involving leading-edge wafer fabrication) with a 73\% share in global production value; wireless local area networks, and digital audio-video equipment like CD-ROM and DVD, with most of these devices being produced in China. Similar dominant world market positions exist for Korea (in computer memories, flat-panel displays and mobile phones), Singapore (storage devices, printers), and China (computers and peripherals and digital consumer devices) (Ernst, 2004b). Furthermore, while India has failed to excel as a global manufacturing exporter, the country has firmly established itself as a global export production base for software and information services.

An equally important aspect of Japan's growing dependence on East Asia are demand-side factors, i.e. the growing sophistication of Asian markets for electronic products and services. ${ }^{9}$ Gone are the days when Asia's protected markets were an easy dumping-ground for low-end and mature products, locally produced by Japanese affiliates (the "mini-Matsushitas"). Procurement by Japanese subsidiaries in Asia has created a thriving market for Japanese exports of parts and components, and capital equipment (Ernst, 2000). The development of rapidly growing electronics industries has further expanded the region's demand for such input imports. Over time, however, the procurement of Japanese subsidiaries and Asian firms has become less Japancentered, substituting imports from Japan with purchases from within the region. Over the last decade, Japanese firms in Asia have substantially increased their localization of sales and procurement (METI, 2002: 10).

To some degree, this reflects the relocation of production by Japanese component suppliers to Asia, as part of an increasingly sophisticated division of labor within Japanese EAPNs (Ernst and Ravenhill, 2000). One important result is that the sales of Asian subsidiaries now outpace Japan's exports to Asia: in fy 2000, Asian subsidiaries recorded sales of Y 36,400 billion, 1.7 
times the value of Japan's exports to Asia (Takeuchi 2003: 13). An equally important cause for the regionalization of procurement by Japanese subsidiaries in Asia has been the emergence of highly competitive suppliers of manufacturing services in Korea, Taiwan, Hong Kong, Singapore, Malaysia, Thailand, Philippines, and more recently China (Ernst, 2003a).

In addition, Japanese electronics firms now belatedly realize the critical importance of Asia's thriving and increasingly sophisticated consumer markets. The contraction of Japan's domestic retail markets for home appliances, audio-video equipment, as well as computing and communication devices provides a powerful incentive for developing aggressive market penetration strategies in Asia (JETRO, 2003: 19). In 2002, total consumer spending in East Asia was estimated to be $\$ 1,461.0$ billion. China's share was almost $40 \%$, up from $27.5 \%$ in 1991.The region's middle and upper class market, the primary target of global competition, is estimated to comprise around 140 million people, roughly $10 \%$ of East Asia's total population. The four NIEs (Singapore, Korea, Taiwan and Hong Kong) dominate these high-end sophisticated consumer markets, but China, with almost 41 million high end consumers, accounts for almost $30 \%$ of the region's higher income market. ${ }^{10}$

Probably the most important change is the growing sophistication of China's markets for electronic products and services. China is now the world's biggest market for telecommunications equipment (wired \& wireless), the third largest market for semiconductors, and one of the largest and most sophisticated markets for digital consumer and computing devices. Major global market leaders count on a continuous rapid growth of the China market to reduce the negative impact of the persistent demand stagnation in global electronics markets. This is true for the telecommunications market where Japanese producers of infrastructure equipment (Fujitsu and NEC) and mobile phones (Matushita, Sharp, Sanyo, Sony, Kyocera) are intensely competing as well as collaborating with global industry leaders (e.g., Motorola, Alcatel, Nokia, Cisco, Samung, Siemens, Ericsson, and LG), and where all of them are 
competing for market share with emerging local giants, such as Huawei, ZTE, Datang, TCL, Haier and Ningbo Bird. Global industry leaders are also eager to penetrate China's markets for computing and consumer devices and key components like semiconductors.

As we will see below, Japanese electronics firms have not been particularly successful in penetrating these markets, and competition has become extremely intense. For the profitable high-end markets, main competitors are Korean (Samsung and LG) and European consumer electronics firms (Philips, Siemens), as well as American computer companies, like HP, Dell, as well as Apple and Gateway, who are now entering at a vengeance the digital consumer market. Competition is even more intense at the mid- and low-level market segments, where in addition to the afore-mentioned firms, Chinese firms and their Taiwanese partners play an increasingly important role. In practically all of these market segments across the region, Japanese firms are on the defensive and are now belatedly trying to repair the damage of earlier inaction.

\subsection{Priorities for Future Network Expansion and Upgrading}

To benefit from the growing importance of East Asia, Japanese electronics firms are now searching for ways to expand and upgrade their EAPNs. The emphasis is on attempts to fine-tune the division of labor between domestic and overseas production, and to reduce reliance on traditional "keiretsu-type" linkages with other Japanese firms. This shift in strategy is driven primarily by the need to expand market share in attractive Asian markets, especially in China and Northeast Asia, and the quest for scale economies that are necessary to cope with intense price competition from emerging new competitors from within the region.

This is a belated attempt by corporate headquarters to transfer to Asia basic changes in the Japanese business model. Of particular importance are attempts to move away from market share expansion to profitability as the main measure of success, and attempts to strengthen vertical specialization, by outsourcing non-core activities. These changes in the Japanese business model 
have been debated at headquarters since the mid-1990s. Yet the green light for implementing such changes in Asia was only given five years later, when the slowdown in the electronics industry gave rise to intensified competition and reduced profits. ${ }^{11}$

Between 2003 and 2005, Japanese manufacturing firms expect to pursue the following priorities in the expansion of their EAPNs (JBICI, 2003: 28, 29). China stands out with a focus on expanding production (almost $73 \%$ out of 518 responses). ASEAN-4 has an equally high focus on expanding production (70\% out of 341 responses). ${ }^{12}$ But while in China this includes investment in new production lines, the focus in ASEAN-4 is almost exclusively on expanding and upgrading existing facilities. In NIEs, expansion of production plays a much less important role, with sales expansion being the dominant concern. In China, Japanese firms also assign a high priority to the expansion of sales functions (almost $60 \%$ of the respondents).

Particularly noteworthy is the low priority assigned by Japanese firms to an expansion of R\&D in Asia. This contrasts with the approach of US and European, as well as Korean and Taiwanese companies, who are expanding R\&D functions in their overseas affiliates in Asia (Choi, 2003; Liu and Chen, 2003). In Asia, the share of Japanese companies that intend to expand R\&D hovers between $9 \%$ (for NIEs) to $13.5 \%$ (for China), compared to $19 \%$ for the EU and almost $23 \%$ in North America. This indicates that Japanese firms apparently continue to neglect the huge potential of Greater China and Korea as lower-cost sources of knowledge workers. Japanese firms, in their attempts to upgrade their Asian networks, still typically try to retain an unequal division of labor that keeps the development and production of leading-edge and high value-added products and production stages in Japan. They also try to minimize possible leakages of technological knowledge. But, as we will see below, their capacity to sustain this "flying geese" pattern of specialization has been critically weakened.

This provides yet another example of the slow pace of response of Japan's major integrated electronics companies. In descending order of asset size, the industry leaders are: Hitachi, Sony, 
Matsushita Electric, Toshiba, NEC, Fujitsu, Mitsubishi Electric, Sanyo and Sharp. With massive overseas sales and extensive global production networks, these nine firms once embodied Japan's global leadership in the electronics industry. With a combined turnover of Y 46 trillion (ca. $\$ 380$ billion), a total workforce of 1.4 million, hundreds of subsidiaries and thousands of component suppliers around the world, adjustments in strategy and organization only come about incrementally.

This is different for Japanese small-and-medium-sized enterprises (SMEs), most of them specialized suppliers of electronic components, who can respond much faster than the global Japanese flagship companies. These SMEs are the main drivers behind the current expansion of production into East Asia. For SMEs, this is a question of survival - smaller Japanese component suppliers are most directly affected by the increasing competition from Asian suppliers. In fy 2002, almost $88 \%$ of suppliers of electronics components were planning to expand their overseas production networks over the next three years, compared to less than $73 \%$ of final assemblers (most of them global flagships). And Japanese SMEs in the electronics industry have a record OPR of $45 \%$, way above the average OPR for all industries of slightly below $32 \%$ (JBICI 2003 : 67).

The rapid internationalization of Japan's domestic supplier base in the electronics industry indicates that the widely feared "hollowing-out" 13 has hit smaller specialized suppliers especially hard. This is borne out by the finding of the fy 2002 JBICI survey (2003: 16ff) that, compared to earlier surveys, fewer companies in the electronics industry intend to invest in an upgrading of domestic operations. Japanese electronics firms may thus lose one of their major traditional strengths, a vibrant and flexible domestic base of supplier industries. ${ }^{14}$

Larger global players on the other hand are under tremendous pressure to combine the expansion of production in Asia with a vigorous upgrading of their domestic production and innovation systems. Laying-off workers in Japan is costly, as retrenched workers must be 
adequately compensated to enable companies to maintain their reputations as good employers. This implies that wages are a de facto component of fixed costs. To sustain jobs especially for expensive knowledge workers, Japanese large firms attempt to sustain an unequal division of labor with Asia. They attempt to keep basic and applied research at home, plus "design work which promotes added-value, and basic programming development", while product and system customization plus process adaptation are developed in major overseas markets like the Asian NIEs and China (JBICI, 2003: 21).

\section{Constraints to Change: Systemic Weaknesses}

To establish why Japanese electronics firms find it difficult to implement the above priorities for future network expansion and upgrading, I highlight five peculiar features of the Japanese network management model in East Asia that once may have reflected strength but now have turned into systemic weaknesses: persistent diversity of organization; dispersed location driven by risk minimization; Japan-centered sales destination and a neglect of local market characteristics; a limited capacity to tap the creativity of non-Japanese skilled workers, engineers and managers; and a reluctance to outsource R\&D.

\subsection{Partial Convergence and Persistent Diversity}

Responding to the resurgence of the U.S. electronics industry during the "New Economy" boom, both the leading global Japanese flagship companies, but also smaller companies like Kyocera, have attempted to emulate what they perceived to be successful strategies by their American counterparts. Imitation has been an important force of change. Yet, imitation has not transformed Japanese companies and their EAPNs into clones of their American benchmark models. Instead it has generated " a complex process of hybridization where partial convergence coexists with persistent diversity" (Ernst and Ravenhill, 2000: 242). ${ }^{15}$ 
Convergence occurred in the mix of products that are produced in Asia. By the mid 1990s, Japanese firms had joined their U.S. counterparts in moving a substantial portion of personal computer production to the region. Japanese firms have also jumped onto the bandwagon of OEM contracts that provided substantial competitive advantages to American computer companies. ${ }^{16}$ Similarly, American firms were the first to take advantage of the growing concentrations of expertise in various areas of electronics production in East Asia by transferring increasing responsibility for engineering and electronic design to subsidiaries (Ernst, 2004a). Again, this has proved to be a cost-effective strategy that some Japanese firms were beginning to emulate since the mid-1990s. The new responsibilities devolved to Japanese subsidiaries have inevitably required changes in management practices that have brought them closer to their American counterparts (Ernst, 2000).

\section{Figure 1: Japan's Integration into the Global Economy}

Yet, important differences persist in the organization of Japanese EAPNs. An important reason for this persistent diversity is that Japan continues to lag behind the US in its integration into the global economy (Fig.1). This truncated integration into global economy constrains any convergence of Japanese networks to the US model. As long as Japan continues to trail behind in its overseas production ratios and especially in its net direct investment income, Japanese firms will remain under pressure to minimize risks by centralizing management control in the parent company, and by relying heavily on the parent and other long-standing partners for the supply of capital goods and components.

\subsection{Dispersed Location}


Until the mid 1980s, affiliates of Japanese electronics firms were more geographically dispersed across Asia than American ones, due to their primary focus on protected local markets. Once the focus shifted to export-platform production, locational patterns converged: both Japanese and American electronics firms invested heavily in mega-plants in a few industrial sites in Malaysia, Taiwan, Singapore, and Thailand. Since the turn of the century, attempts to be more selective have gained momentum. Japanese firms are now attempting to gain scale economies through consolidation of investment in China, and to catch up with global competitors in the penetration of the China market.

A huge investment gap however remains in the China market between US, European and Korean companies on the one hand and Japanese companies on the other. The first group has focused on consolidating in China much of its global production, serving both the Chinese and global markets, and hence maximizing both economies of scale and scope. In contrast, as a share of Japan's accumulated stock of FDI, China still lags substantially behind Asian NIEs and ASEAN 4 (figure 2).

Figure 2: Japanese FDI Stock, by destination, 2002, \$bn

In China, Japanese electronics firms have invested in production much earlier than the first group of companies, but they were constrained, because the Chinese government did not allow foreign firms to invest in the final-product manufacturing of electronics products, except for a few export-oriented joint ventures, primarily by Hitachi and Sanyo (Marukawa, 2002: 184187). ${ }^{17}$ This is why, during the "China fever" between 1991 and 1995, Japanese electronics firms in China concentrated on the production of key components for the consumer electronics industry. By providing key components like CRTs, compressors and ICs to Chinese set makers, and by assisting their IC design, Japanese firms supported the development of technological capabilities by Chinese firms that are now industry leaders, like Haier, Konka, TCL and others. 
Japanese electronics firms, however, were unable to enjoy first-comers' advantages, such as Shanghai Volkswagen did for cars, and they failed to establish strong positions in China's final product markets. This is true even for consumer electronics, a market that Japanese firms dominate in Southeast Asia. It thus made perfect economic sense for Japanese firms to sustain a dual production base both in Southeast Asia and in China. Today, this dispersion of production networks across Asia has become a major disadvantage, as it prevents Japanese firms from reaping cost-reducing scale economies in China.

Attempts to shift the center of gravity of Japanese EAPNs from ASEAN to China are constrained by a deeply entrenched history of Japanese management trying to shelter the company from risks and uncertainties (Tachiki, 1999:186). ${ }^{18}$ Japanese firms are concerned that once they move most of their investment into China, their profitability will suffer, as they become unduly dependent on an array of perceived disadvantages and risks of investing in China. A major concern is that the legal framework and the tax system are opaque, and that both are prone to frequent, sudden and unpredictable changes. Equally important are concerns about the absence of effective intellectual property rights (IPR) protection, difficulties to raise local investment funds, and delays in the collection of account receivables, while Japanese firms are requested to settle accounts immediately. Japanese electronics firms are also concerned about an industry structure that gives rise to "excessive" competition and periodic over-heating, and a tendency to shirk WTO regulations and to introduce hidden non-tariff barriers (JBICI, 2003: 34).

A fourth major area of concern relates to the availability of local managers and engineers and labor relations. Japanese electronics firms are concerned that the rising cost of managers and engineers in China may soon reduce the cost advantage relative to other locations in Asia. ${ }^{19}$ Frequent complaints are about high employee turnover, low level of basic factory skills, and conflicts about wage level gaps between Japanese staff and Chinese workers. Because of these perceived difficulties and risks, Japanese electronics firms typically are very reluctant to move 
from dispersed Asian production networks to concentrated networks within China. Risk minimization in other words limits the pursuit of vertical specialization, and this sets Japanese companies apart from their American and European counterparts.

But recently there are signs of a possible reversal: Japanese FDI into China, which had stagnated in value since fy 1995, has increased again for the first time in fy 2000 (JETRO 2002b: 35). ${ }^{20}$ Since then, Japanese FDI inflows into China have accelerated, rising almost $60 \%$ in 2001 , to $\$ 4.6$ billion, the highest level ever. And during the first six months of 2002, Japanese firms invested an additional $\$ 3.15$ billion (JBICI 2003). ${ }^{21}$ Like during the first "China Fever" in 1992 , the Yen appreciation has acted as a powerful catalyst. However, there are now additional attractions, such as: substantial improvements in infrastructure and logistics, at least in China's three main growth poles; the signaling effect of China's WTO accession; the emergence of support industry clusters; and vast improvements in the quality of human resources, especially China's ca. 700,000 annual science and engineering graduates.

\subsection{Sales Destination - Neglect of Asian Markets}

A third persistent difference can be found in the contrasting sales destination of Japanese and American EAPNs (Takeuchi 2001). While Japanese electronics companies have moved from sales to local markets to third country exports, and now to reverse importing into Japan, American companies have moved in the opposite direction: from a primary focus on reverse imports into the U.S: to an increasing emphasis on sales in Asia. Throughout the 1990s, a defining characteristic of Japanese EAPNs in the electronics industry has been the rapid rise of reverse imports into Japan - more than $60 \%$ of Japan's imports from Asia are imports from Japanese subsidiaries (METI, 2002).

By the turn of the century, Asia has replaced the U.S. as the main source of Japanese imports for computers, semiconductors and electronic components. For semiconductors, Japan's import 
dependence ratio $^{22}$ grew rapidly from below $20 \%$ in 1991 to around $50 \%$ in 1999 . This was primarily due to foundry contracts and contract manufacturing arrangements for semiconductors, primarily with Taiwanese and Singaporean firms. By 2000, Asia accounted for over $60 \%$ of Japan's semiconductor imports, while the share of the U.S. had fallen to around $30 \%$. This has resulted in a dramatic reversal of Japan's trade balance with Asia in the electronics industry from surplus into deficit.

The Japan-centered sales destination has resulted in another major weakness of Japanese EAPNs: a lack of aggressive strategic marketing to address the specific requirements of East Asian markets (e.g., Meyer-Ohle and Hirasawa, 2000). Japanese firms are on the defensive in practically all important electronic market segments across Asia, and they are now belatedly searching for ways to repair the damage of earlier inaction. Throughout Asia, and especially in China, Japanese electronics firms have failed to develop and exploit unique market positions. In consumer electronics for instance, Japanese majors like Sony and Matsushita have been caught in price wars with the dominant local players, while in the high-end markets, they are lagging behind Korean and European set makers, like Samsung, LG and Philips. And for computing and communication devices, Japanese firms seem to be in a sandwich. On the one hand they have difficulties advancing into the new product, software and service markets developed by US leaders, e.g. the Internet, e-business, advanced microprocessors, and operating systems for an increasing variety of digital devices. On the other hand, for price-sensitive devices, like laptops and mobile phones, Japanese firms are been squeezed by global brand leaders from the US, Europe and Korea, who are outsourcing manufacturing and design to low-cost EMS and ODM suppliers, as well as by Chinese set-makers who can gain access to latest product technology, say for smart phones, by licensing reference designs and so-called silicon intellectual properties (SIPs), i.e. building blocks that facilitate SOC (system-on-chip) design (Ernst, 2004b). 
In China specifically, Japanese electronics firms need to differentiate themselves from their increasingly important Asian (primarily Korean and Chinese) competitors. Debates on how to improve their market position emphasize that it is necessary to " maintain non-price competitiveness in areas where differentiation is possible in terms of technology and know-how" (Konomoto 2002: 8). But to achieve this will not be easy. Take China's mobile communications market which has experienced exponential growth, tripling in value between 1998 and 2002. Reflecting China's WTO membership obligations, foreign companies can establish joint ventures in China as of January 2003, for mobile phones, data communications, fixed telephones, and international telephone services. Furthermore, China's government is expected to introduce $3 \mathrm{G}$ mobile phone service during 2005.

To succeed in China's telecommunications market, global companies must be willing to share their accumulated experience in providing "integrated solutions" for complex technology systems. According to Davies et al (2001:5), “integrated solutions" encompass four sets of capabilities: (1) system integration: to design and integrate components and subsystems into a system; (2) operational services: to maintain, finance, renovate and operate systems through the life cycle; (3) business consulting: to understand a customer's business and to offer advice and solutions that address a customer's specific needs; and (4) finance: to provide a customer with help in purchasing new capital-intensive systems and in managing a customer's installed base of capital assets. By and large, US and European electronics firms have sophisticated and proven strategies in place that can provide these four critical support services.

Japanese firms (both equipment vendors and service providers) lag well behind their rivals from the US and Europe in the penetration of China's communications markets. For instance, NEC and Matsushita Communications Industrial have established a joint venture to develop 3G mobile handsets at the end of 2001. But as this venture was about to become operational during 2003, price competition had already drastically increased for mobile handsets. Intense price 
competition is driven primarily by purely Chinese manufacturers like Ningbo Bird, TCL, Legend and others who can provide low-cost handsets, based on key components and reference designs that they have licensed from global platform leaders like Ericsson, Texas Instruments and Philips. In short, Japanese firms may have again missed the opportunity to reap first mover windfall profits.

There are various reasons why Japanese firms thus far have made little headway in penetrating China's emerging "systems solutions" markets. Probably of greatest importance are constraints imposed by the Japanese production system that prevent Japanese electronics firms from sharing "integrated solutions" capabilities. As convincingly demonstrated by Yoshihara (2000:67 and 68), Japanese parent companies typically insist on an (almost) exact replication of plant layout, quality control and management routines in overseas subsidiaries, and they exercise tight control over capabilities required for "integrated solutions." This unwillingness to share the basic ingredients of the Japanese production system with outsiders has become a major stumbling block for Japanese penetration strategies into the China market.

\subsection{Human Resources Management}

Human resources management (HRM) used to be considered a major advantage of the Japanese business model (e.g., Dore, 1986; Aoki, 1988; Nonaka and Takeuchi, 1995; Fruin, 1997). Somewhat ironically, it has now become an important weakness. No other factor arguably constrains Japanese electronics firms in East Asia more than their very limited capacity to recruit, develop and benefit from non-Japanese skilled workers, engineers and managers. In China, for instance, European and American firms put enormous energy and money into training Chinese staff and promoting them on the corporate ladder. Japanese companies have instead bred "China experts" - Japanese fluent in Chinese who have studied Chinese business practice and 
behavior. These Japanese managers maintain a firm grip on business and keep their Chinese colleagues at a distance.

Typically, Japanese companies manage their Asian subsidiaries in a top-down, bureaucratic way. The main objective is to make sure that the subsidiary responds faithfully to orders from Japan, which requires hard task master managers. Existing organizational structures and incentives do not help to breed initiative and innovation. Such a top-down HRM approach worked, as long as the main objective was to exploit low labor costs. Typically, Asian subsidiaries produced lower-end, commodity-type products to a given design, and they provided a narrower range of products and services than in Japan. As a result, it was relatively easy for Japanese expatriate managers to convey the wishes of headquarters' management to the shop floor. The main task was to achieve results, and there was not much need to listen to local subordinates. This system however provides very little flexibility: without the Japanese expatriates, the subsidiaries cannot function. As Japanese managers make most decisions among themselves, they "often find themselves making decisions based on hearsay (e.g., about what strategies rivals may have adopted) and guesses (e.g., about what customers may be thinking)." (Konomoto, 2000: 9). ${ }^{23}$

I experienced a vivid example of this system during an interview in November 2002 with the general manager of a subsidiary of one of the largest Japanese electronics conglomerates in China. As he spoke only Japanese, he brought along two interpreters, one to translate between Japanese and English, to communicate with me, and one interpreter to communicate with his Chinese middle managers (altogether six representing the main functions of the subsidiary, like sales, production, quality control, $R \& D$, procurement). Under these conditions, communication was not easy, and required a quite extraordinary amount of concentration on all sides, in order to avoid a Babylonian mix-up. Fortunately enough, the Japanese GM was mild-mannered and good-humored. But what was supposed to be a standard $1 \frac{1}{2}$ hours interview, required almost 
three hours. Even then, we had not achieved what we wanted to discuss, but all participants agreed to end the interview, due to sheer exhaustion.

Such communication barriers are ever present in Japanese subsidiaries in Asia: "the cultural and linguistic gap between expatriate Japanese managers and local employees has obscured the latter's true feelings from the former" (Konomoto, 2000: 10), giving rise to misunderstandings and mutual recriminations. This has had a negative impact on local staff morale. In addition, obscure selection criteria for choosing local senior managers, and persistent "glass ceilings" for non-Japanese managers de-motivate local employees - "veteran employees arrange with each other to do the minimum amount of work necessary and wait for instructions rather than volunteer suggestions" (Konomoto, 2000: 6). Japanese subsidiaries are especially weak in motivating higher-skilled local employees with scarce skills: "The greater the educational qualifications of employees..., the more they tended to be dissatisfied with the company's merit orientation.” (ibid.). Unsurprisingly, higher-skilled employees tend to search for a quick return, especially in the highly competitive skilled labor markets of China.

An important reason for these communication barriers is that headquarters management in Japan fails to examine the motivations of local managers and engineers that shape the corporate culture of Japanese subsidiaries. This gives rise to a vicious circle. Because of an unwillingness to promote local managers to top positions and because of the operation of a seniority system that inhibits rapid promotion, Japanese companies have found it difficult to recruit and retain quality managers and engineers in their Asian subsidiaries. Japanese managers typically argue that they cannot feel confident about increasing the role of local management, "because the skill level of locally recruited managers is low."(JBICI, 2001: 68). They continue to have great difficulties in Asia in recruiting top technical talents and local managers. Linguistic barriers are one important reason: the capacity to speak Japanese is often a basic prerequisite for hiring local managers, but Asian managers prefer to learn English. ${ }^{24}$ 
Another reason is the negative image of Japanese firms as employers of skilled labor. Surveys have shown that most Asian managers consider working conditions and promotion opportunities in U.S. subsidiaries to be far more favorable, placing Japanese subsidiaries at a competitive disadvantage. The rapid expansion of the electronics industry in Asian has offered high caliber personnel the opportunity for movement among employers. Extensive "job-hopping" is the name of the game, a phenomenon that Japanese corporations have found alien.

To address this problem, Japanese electronics firms have adopted a strategy of in-house training of their engineers. Based on a careful selection process, an affiliate in Asia develops a pool of highly motivated operators which they then train over a period of five to seven years to become (sometimes unlicensed) engineers. In this manner, engineering skills are made firmspecific, reducing the likelihood of job-hopping behavior. ${ }^{25}$ The disadvantage however is that this requires a lot of time. Most importantly, this reliance on "internal recruitment" gives rise to an increasingly serious failure to compete for the best local management and engineering talents across the region who could provide new ideas and a fresh commitment to upgrade Japanese EAPNs.

Japanese electronics firms recognize that they must drastically change their human resources management (HRM) practices in East Asia. They are searching for ways to catch up with more open, flexible and decentralized HRM approaches of global industry leaders, including those of Korean and Taiwanese competitors. Japanese firms know that without such changes in HRM, "any competition strategy they have will prove ineffective." (Konomoto, 2000: 1). After years of hesitation, Japanese firms are now eager to tap into East Asia's huge pool of lower-cost managers and engineers to facilitate and accelerate decision-making, and to cope with the frantic pace of change in Asian business practices, values and ways of thinking (JETRO, 2003: 33).

Necessary changes in HRM include the introduction of transparent performance evaluation criteria, adapted to local routines and labor market regulations, and career perspectives that 
match those of competing US, European and Asian firms. Above all, local staff needs to become an integral part in the decision-making process and in the search for problem solutions. Furthermore, local managers need to be groomed for and transferred to global positions, like for instance Motorola does when it sends the general manager of its Penang subsidiary to manage its newly established Chinese facilities. ${ }^{26}$ This high inter-firm and geographic mobility of local senior managers that work for US global network flagships contrasts with the Japanese approach of promoting the intra-firm transfer of (overwhelmingly) Japanese managers.

\subsection{R\&D Management}

Before the mid 1990s, Japanese corporations undertook little R\&D in their East Asian subsidiaries. This contrasts with U.S. subsidiaries whose parents increasingly delegated to them responsibility for product design and development, in some instances not just for local but global markets (Ernst, 1997). By the turn of the century, R\&D continued to play a limited role in the EAPNs of Japanese firms, compared to North America and the EU. But as East Asian customers become increasingly demanding, Japanese firms can no longer rely on products designed in Japan to penetrate Asian markets. Instead, localization of design and engineering is necessary to customize products and services, and to accelerate speed of response to changes in demand. Successful market penetration in East Asia thus requires a break with established patterns in R\&D management.

Yet we have seen that Japanese firms continue to assign a low priority to an expansion of R\&D in East Asia. This reflects a defensive bias of Japanese R\&D management: intellectual property rights (IPR) protection and restrictions on royalty payments are the predominant concern. This is in stark contrast to R\&D management in American electronics companies where value creation through aggressive commercialization of a company's intellectual property rights now has become the top priority. Leading competitors in the US, Europe and Korea have 
aggressively moved ahead with R\&D outsourcing to tap into the region's vast lower-cost pool of human resources and specialized skills. Japanese firms thus need to complement IPR protection with a consistent strategy to relocating more R\&D to major new clusters in East Asia (e.g., Walsh, 2003).

However, after a long period of reluctance, Japanese firms are finally investing in R\&D centers, both in China and Southeast Asia, and the focus is shifting from product customization and process adjustment to chip design and software services. ${ }^{27}$ However, retaining control over core production technologies remains a dominant concern, reflecting fears that Japan's competitiveness might be eroded by leaking production technologies overseas (JETRO 2003: 44). ${ }^{28}$ This reluctance to penetrate aggressively Asia's emerging technology markets runs counter to important long-term interests of Japanese electronics firms. As Takeuchi (2003: 17) demonstrates, Japanese firms need to increase their revenues from both FDI and technology licensing, in order to compensate for declining export revenues. Some Japanese industry leaders have developed robust leadership positions in key technologies such as system-on-chip design, liquid crystal and plasma displays, and nano-technology. ${ }^{29}$ This should help them to bear the risks of relocating some parts of $R \& D$ to East Asia.

\section{Hybridization - Partnering with Asian Companies}

Japanese electronics firms are now searching for ways to readjust their production, distribution and innovation networks to cope with the opportunities and challenges resulting from the increasingly complex regionalization in a radically changed East Asia. This constitutes a fundamental change in Japanese corporate strategy and organization. At long last, Japanese electronics firms appear ready to accept that they are no longer capable of imposing an unequal "flying geese" division of labor on East Asia. Equally important, the belief in the innate superiority of the Japanese business model has become an endangered species - Japanese 
electronics firms are all searching to emulate successful features not only of American and European rivals, but also of leading Korean, Taiwanese and Chinese firms. For the first time, Japanese electronics firms are now also using successful Asian firms, like Samsung, LG, Acer (BenQ), Hon Hai, Haier and TCL as benchmark cases to reformulate their regional networking strategies. And they are searching for ways to develop strategic partnerships with emerging new industry leaders in Asia, most prominently with Chinese companies.

Some Japanese firms are belatedly following the partnering strategies pioneered by global industry leaders like Motorola, Intel, IBM, Cisco, Alcatel, Philips, Siemens, Infineon, but also by Korea's “Big Four” (Samsung, LG, SK Telecom and KT), Singapore's Temasek, and Taiwan's industry leaders. ${ }^{30}$ Particularly instructive is a recent partnerships between Sanyo and Haier (announced in January 2002) which shows signs of a radical break with a tradition of unequal ("vertical") forms of collaboration, where the Japanese partner dominates, to a "horizontal" relationship among equals. As the first attempt by a major Japanese electronics company to establish a comprehensive business alliance with a Chinese industry leader, the Sanyo-Haier agreement has been hailed by METI as the new "standard for Japan-China business relationships...Rather than antagonizing Chinese players, Japanese businesses should team up with them to share profits in mutual markets." ${ }^{31}$ But this agreement has also encountered "an enormous number of protest from various sides", ${ }^{32}$ indicating the still substantial resistance of Japanese firms against changes in their China strategies.

The agreement has four components: 1) sales of Sanyo products in China under Sanyo and Haier brand names through Haier's distribution network; 2) sales of Haier products in Japan through a joint venture in Japan, with Sanyo owing 60\% and Haier 40\%; 3) a new Sanyo factory to be built next to Haier's huge refrigerator factory in Tsing Tao, to supply Haier with Sanyo's leading-edge compressors; and, most importantly, 4) technological collaboration across a broad range of key components. 
For Sanyo, important benefits include a privileged access to Haier's vast sales network in China, the largest of any electronics company. ${ }^{33}$ Additional attractions are Haier's market leadership across a broad product portfolio; ${ }^{34}$ Haier's state-of-the-art production system; and most importantly, a highly motivated and well-trained workforce (with a high share of engineers and managers trained in the US) that is exposed to strictly enforced performance-based evaluation and incentives. Sanyo's CEO, Satoshi Iue (the son of the company's founder) was greatly impressed during an earlier visit to a massive Haier Group plant that is four times larger than his own company's largest factory. ${ }^{35}$ He was particularly impressed by Haier's ability to purchase the sort of expensive, leading-edge machinery (primarily from European suppliers) that is beyond the reach of Japanese manufacturers, due to their financial difficulties. ${ }^{36}$

For Haier, in turn, the main attraction has been Sanyo's willingness to market and support its products in the Japanese market, an absolute first in the notoriously closed Japanese market. Haier understands that it will take time to overcome resistance of Japanese customers, due to the persistent "low quality" image of Chinese products. But it expects to use Sanyo's decision to support its products in the famously difficult Japanese market to enhance its brand recognition in other markets, including the increasingly demanding Chinese market. Although several leading Japanese firms had been courting Haier, it appears that no other company was willing to follow Sanyo's offer of a comprehensive business alliance that includes broad-based technological cooperation.

Arguably the most interesting development is a new sense of urgency on the part of Sanyo managers to make a serious effort to overcome communication problems with their Chinese counterparts, and to adjust to modern Chinese business practices. Symptomatic is the approach taken by the 35 -year-old president of the Sanyo Haier joint venture. ${ }^{37} \mathrm{He}$ admits that this comprehensive business alliance is " a new type of project that Sanyo has no experience with. 
Dealing with the Chinese style of business creates problems I've never faced before, but... I am comfortable with it and enjoy this challenge." To illustrate this, he tells the following story:

"The Chinese way of starting business is to take orders regardless of their capabilities to fill the orders at the time. When they are asked to do something, the Chinese normally respond by saying, 'It can be done.' This means an absolute commitment in Japan, but, it is used in China to express one's eagerness to do business...In such a situation, the Japanese would respond by saying, 'We'll take it back to our office to determine whether we can accept the job.' In the beginning, we trusted the Chinese counterpart's words and began doing our part. After a while, we found out our partner could not live up to its part of the agreement. That was our mistake - we should have been aware it was the Chinese way of getting orders, and we shouldn't have taken their first response as a full commitment.. I have finally come to understand that they are not malicious (underlining added, DE)... I admire the eagerness and aggressiveness of the Chinese toward business. The Japanese tend to be too humble and uncertain when doing business. The Chinese are more determined, and I think that has led to their recent economic growth."

\section{Conclusions}

This chapter has demonstrated that, far from withdrawing from East Asia, Japanese corporate capital in the electronics industry now critically depends on the region, not only as a global export production base, but also as a major and increasingly sophisticated market for its products, services and technology, and as a source of lower-cost knowledge workers. This explains why Japanese electronics firms are searching for ways to expand and upgrade their regional distribution, production and R\&D networks, with a particular focus on China. These networks will continue to affect Asian regionalization patterns, but their impact will now differ 
from earlier periods. I have shown, for instance, that Japan's trade links with Asia have shifted from surplus to deficit, and that important changes have occurred in the composition of traded products. Japanese firms continue to be a major source of components and machinery. They also continue to play an important role as providers of shop-floor management techniques for Asian suppliers (e.g., quality control and supply chain management). But in many other areas of management, Japanese firms now play second fiddle.

We have seen that Japanese firms are finding it difficult to make the adjustments in organization and management that are necessary to expand and upgrade their regional networks. I have highlighted five peculiar features of the Japanese network management model in East Asia that once may have reflected strength but now have turned into systemic weaknesses: persistent diversity of organization; dispersed location driven by risk minimization; Japancentered sales destination and a neglect of local market characteristics; a limited capacity to tap the creativity of non-Japanese skilled workers, engineers and managers; and a reluctance to outsource R\&D.

I have also identified equally important exogenous forces. In the electronics industry, firms of diverse nationality compete and collaborate within multi-layered global "networks of networks" of marketing, production and innovation. This has forced Japanese firms into dense interaction with a multitude of firms from the US as well as from East Asia's leading electronics exporting countries. A second critical exogenous force has been the rise of China as a global export production base, as a sophisticated growth market, especially for mobile communications and digital consumer devices, and as a new source of R\&D and innovation. Both forces have produced increasingly complex processes of regionalization.

The chapter shows that, to cope with the new challenges they are facing in a radically changing East Asia, Japanese firms are now beginning to emulate successful features of Korean, Taiwanese and Chinese business models. Belatedly, some Japanese firms are now attempting to 
develop more equal partnerships with emerging new industry leaders in Asia, primarily from Greater China. This "out-lier behavior" may act as a powerful catalyst for change. The key to successful alliances with Asian partners is "hybridization" of business organization beyond national models, where Japanese firms adopt successful features of East Asian firms. In this sense, "Asianization" of production networks may supersede in the longer run the battle between "Japanization" and "Americanization." 
Figure 1: Japan's Integration into the Global Economy

\begin{tabular}{|l|c|c|c|}
\hline & Japan & U.S.A. & Germany \\
\hline Balance of Overseas Direct & 5.9 & 25.0 & 22.7 \\
Investment/GDP & & & \\
\hline Overseas Production Ratio & 14.3 & 30.7 & 46.8 \\
\hline Net Direct Production Ratio & 4.9 & 103.2 & 4.6 \\
$\quad$ Income Received & 8.2 & 149.3 & 16.8 \\
$\quad$ Income Paid & 2.6 & 68.0 & 9.6 \\
$\quad$ License Royalties, etc. Received & 10.2 & 38.0 & 2.8 \\
$\quad$ License Royalties, etc. Paid & 11.0 & 16.1 & 5.5 \\
\hline Net Direct Investment Income/GDP & 0.1 & 0.8 & 0.4 \\
\hline Net Direct Investment & 3.0 & 6.0 & 4.0 \\
Income/Investment Balance & & & 26.3 \\
\hline Export Reliance & 9.7 & 7.8 & 26.3 \\
\hline Import Reliance & 7.2 & 12.4 & 23.6 \\
\hline Balance of Inward Direct & 1.1 & 27.7 & \\
Investment/GDP & & & \\
\hline
\end{tabular}

Notes: The figures are actual date for 2000, except for the overseas production ratio for the United States, which refers to 1999.

Source: Takeuchi, 2003

Figure 2: Japanese FDI Stock, by destination, 2002, \$bn

\begin{tabular}{|c|c|}
\hline NIEs & 24.9 \\
\hline ASEAN -4 & 18.78 \\
\hline China & 12.48 \\
\hline
\end{tabular}

Source: Compiled from JETRO, 2003 


\section{References}

Aoki, Masahiko, 1988, Information, Incentives and Bargaining in the Japanese Economy, Cambridge University Press, Cambridge

Chandler, A.D. (1977), The Visible Hand: the Managerial Revolution in American Business, Cambridge, US: Harvard University Press.

Cheng, L.K. and H. Kierzkowski, eds, 2001, Global Production and Trade in East Asia, Kluwer Academic Publishers, Boston etc

CHI/MIT, 2003, report on "Innovation Scores" survey, at CHI.com

“China Alliance Brings Opportunity, Problems", The Yomiuri Shimbun, 23 September 2002

Choi, Chang-Hee, 2003, "The China Strategies of Korea's Winning Companies", NRI Papers No.67, Nomura Research Institute, Tokyo, August 1

Davies, A., P. Tuang, T. Brady, M. Hobday, H. Rush, D. Gann, 2001, Integrated Solutions = the New Economy between Manufacturing and Services, Science Policy Research Unit (SPRU), University of Sussex, December

“Deal Sees Sanyo, Haier as Equals", Asahi Shimbun, 10 January 2002.

Dore, Ronald, 1986, Flexible Rigidities. Industrial Policy and Structural Adjustment in the Japanese Economy 1970-80, The Athlone Press, London

Dunning, John (1981), International Production and the Multinational Enterprise, George Allen \& Unwin, London

Encarnation, Dennis J., 1999, ed., Japanese Multinationals in Asia. Regional Operations in Comparative Perspective, Oxford University Press, New York etc

Ernst, Dieter, forthcoming, "China's Late Innovation Strategies in the Electronics Industry The International Dimension", International Journal of Technology and Globalization 
Ernst, Dieter, 2004a, "Late Innovation Strategies in Asian Electronics Industries - A Conceptual Framework and Illustrative Evidence”, in Oxford Development Studies, special issue in honor of Linsu Kim

Ernst, Dieter, 2004b, “Internationalisation of Innovation: Why is Chip Design Moving to Asia?", in International Journal of Innovation Management, special issue in honour of Keith Pavitt; also available as East-West Center Economics Working Paper \# 64

Ernst, Dieter, 2003a, “The New Mobility of Knowledge: Digital Information Systems and Global Flagship Networks", East-West Center Economics Working Papers, No. 56, June, forthcoming in: Latham, R. and S. Sassen (eds.), Digital Formations in a Connected World, published for the U.S. Social Science Research Council, Princeton University Press

Ernst, Dieter, 2003b, "Digital Information Systems and Global Flagship Networks: How Mobile is Knowledge in the Global Network Economy?", in: J.F. Christensen (ed.), The Industrial Dynamics of the New Digital Economy, Edward Elgar, Cheltenham

Ernst, D., 2002a, “The Economics of Electronics Industry: Competitive Dynamics and Industrial Organization", in: The International Encyclopedia of Business and Management (IEBM), Handbook of Economics, editor: William Lazonick, International Thomson Business Press, London

Ernst, D., 2002b , "Global Production Networks and the Changing Geography of Innovation Systems. Implications for Developing Countries", Journal of the Economics of Innovation and New Technologies, Vol. XI, \#6, pp. 497-523

Ernst, Dieter, 2000, "Evolutionary Aspects: the Asian Production Networks of Japanese Electronics Firms”, In: Borrus, M., D. Ernst and S. Haggard (eds.), International Production Networks in Asia. Rivalry or Riches?, Routledge, London

Ernst, Dieter, 1997, From Partial to Systemic Globalization. International Production Networks in the Electronics Industry, report prepared for the Sloan Foundation, jointly published 
International Relations and Pacific Studies, University of California at San Diego

Ernst, Dieter and Linsu Kim, 2002, “Global Production Networks, Knowledge Diffusion and Local Capability Formation", Research Policy, special issue in honor of Richard Nelson and Sydney Winter, volume 31, no. 8/9, pp. 1417-1429

Ernst, Dieter and John Ravenhill, 2000, “Convergence and Diversity: How Globalization Reshapes Asian Production Networks", in: Borrus, M., D. Ernst and S. Haggard (eds.), International Production Networks in Asia. Rivalry or Riches?, Routledge, London

Ernst, Dieter and Paolo Guerrieri, 1998, "International Production Networks and Changing Trade Patterns in East Asia. The Case of the Electronics Industry", Oxford Development Studies, Vol.26, No.2, June

Feenstra, Robert, (1998), 'Integration of Trade and Disintegration of Production in the Global Economy', The Journal of Economic Perspectives, 12/4, 31-50

Fruin, W. Mark, 1997, Knowledge Works. Managing Intellectual Capital at Toshiba, Oxford University Press, New York etc

Hatch, Walter and Kozo Yamamura, 1996, Asia in Japan's Embrace. Building a Regional Production Alliance, Cambridge University Press

Ishiyama, Yoshihide, 1999, “Is Japan Hollowing Out?”, in: Dennis J. Encarnation, Dennis J., 1999, ed., Japanese Multinationals in Asia. Regional Operations in Comparative Perspective, Oxford University Press, New York etc

JBICI, 2003, Survey Report on Overseas Business Operations by Japanese Manufacturing Companies - Results of JBIC FY 2002 Survey, Japan Bank for International Cooperation Institute (JBICI) 
JBICI, 2001, Survey Report on Overseas Business Operations by Japanese Manufacturing Companies - Results of JBIC FY 2000 Survey, Japan Bank for International Cooperation Institute (JBICI), Tokyo

JETRO, 2003, 2003 JETRO White Paper on International Trade and Foreign Direct Investment, Japan External Trade Organization, Tokyo

JETRO, 2002, 2002 JETRO White Paper on International Trade and Investment, Japan External Trade Organization, Tokyo

Kojima, Kiyoshi, 1986, “Japanese-Style Direct Foreign Investment”, Japanese Economic Studies, $14(3): 52-82$

Kojima, Kiyoshi, 1978, Direct Foreign Investment: A Japanese Model of Multinational Business Operations, Croom Helm, London

Konomoto, Shingo, 2002, “China's Rapidly Growing Infocom Industry and Approaches by Japanese Companies”, NRI Papers No.53, Nomura Research Institute, Tokyo, August 1

Konomoto, Shingo, 2000, "Problems of Japanese Companies in East and Southeast Asia", NRI Papers No.18, Nomura Research Institute, Tokyo, November 1

Liu, Meng-Chun and Shin-Horng Chen, 2003, "International R\&D Deployment and Locational Advantage of Developing Countries: A Case Study of Taiwan”, Chung-Hua Institution for Economic Research, Taipei

“Machine Tools: A Shrinking Domestic Market”, Asahi Shimbun, 6 February 2002).

Marukawa, Tomoo, 2002, “Japanese FDI and China's Industrial Development in the Automobile, Electronics and Textile Industries", in Hanns Guenther Hilpert and Rene Haak, eds., Japan and China: Cooperation, Competition and Conflict, Palgrave, Basingstoke etc

METI, 2003, Summary of the $32^{\text {nd }}$ Survey of Overseas Business Activities, Ministry of Trade \& Economics (METI), June 16, Tokyo 
METI, 2002, Summary of the $31^{\text {st }}$ Survey of Overseas Business Activities, Ministry of Trade \& Economics (METI), May 17, Tokyo

Meyer-Ohle, Hendrik and Katsuhiko Hirasawa, 2000, "Marketing Strategies of Japanese Firms: Building Brands with a Regional and Long-Term Perspective", in Jochen Legewie and Hendrik Meyer-Ohle, eds., Corporate Strategies for Southeast Asia after the Crisis: A Comparison of Multinational Firms from Japan and Europe, Palgrave, Basingstoke etc

Nakagane, Katsuji, 2002, “Japanese Direct Investment in China: Its Effects on China’s Economic Development", in Hanns Guenther Hilpert and Rene Haak, eds., Japan and China: Cooperation, Competition and Conflict, Palgrave, Basingstoke etc

Ng, Francis and Alexander Yeats, 2003, "Major Trade Trends in East Asia. What are their Implications for Regional Cooperation and Growth?”, World Bank Policy Research Working Paper No 3084, World bank, Washington, D.C., June

Nonaka, Ikujiro and Hirotaka Takeuchi, 1995, The Knowledge-Creating Company. How Japanese Companies Create the Dynamics of Innovation, Oxford University Press, New York etc Ozawa, Terutomo, 2003, "Pax Americana-Led Macro-Clustering and Flying-Geese-Style Catch-Up in East Asia: Mechanisms of Regionalized Endogenous Growth", Journal of Asian Economics, 13: 699-713

Ozawa, Terutomo, 2000, "The "Flying-Geese" Paradigm: Toward a Co-evolutionary Theory of MNC-Assisted Growth", Khosrow Fatemi (ed.), The New World Order: Internationalism,

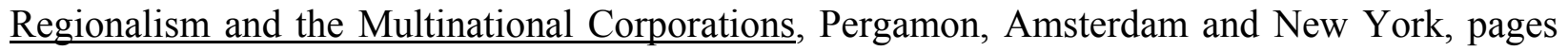
209-223

Ozawa, Terutomo, 1979, Multinationalism, Japanese Style: The Political Economy of Outward Dependency, Princeton University Press, Princeton

Posner, M.,1961, “International Trade and Technical Change”, Oxford Economic papers, Vol 13: $323-42$ 
Roach, S., 2003, “The world is more US-centric now than it has ever been", presentation by the chief economist of Morgan Stanley to the World Economic Forum 2003

"Sanyo-Haier Group Alliance Offers Lucrative Foothold”, The Nikkei Weekly, 15 January 2002.

Tachiki, Dennis S., 1999, "The Business Strategies of Japanese Production Networks in Asia”, in Dennis J. Encarnation, ed., Japanese Multinationals in Asia. Regional Operations in Comparative Perspective, Oxford University Press, New York etc

Takeuchi, Junko, 2003, “The Effect of Free Trade Agreements on the Activities of Japanese Companies in Asia”, RIM. Pacific Business and Industries, Vol. III, No.10: 2-23

Takeuchi, Junko, 2001, "Comparison of Asian Business by Japanese and American Companies in the Electronics Sector", RIM. Pacific Business and Industries, Vol. I, No.3: 18-44 Urata, Shujiro, 1999, "Intrafirm Technology Transfer by Japanese Multinationals", in Dennis

J. Encarnation, ed., Japanese Multinationals in Asia. Regional Operations in Comparative Perspective, Oxford University Press, New York etc

Vernon, R., 1966, “International Investment and International Trade in the Product Cycle”, Quarterly Journal of Economics, Vol. 80: 190-207

Vernon, R., 1979, “The Product Cycle Hypothesis in a New International Environment", Oxford Bulletin of Economics and Statistics, Vol. 41: 255-268

Walsh, Kathleen, 2003, Foreign High-Tech R\&D in China. Risks, Rewards and Implications for U.S.-China Relations, The Henry L. Stimson Center, Washington, D.C.

Westney, D. Eleanor, 1999, "Changing Perspectives on the Organization of Japanese Multinational Companies", in Schon L. Beechler and Allan Bird, eds., Japanese Multinationals Abroad. Individual and Organizational Learning, Oxford University Press, New York etc Yoshihara, Hideki, 2000, “Options for Strategic Change: Screwdriver Factories of Integrated Production Systems", in Jochen Legewie and Hendrik Meyer-Ohle, eds., Corporate Strategies for 
Southeast Asia after the Crisis: A Comparison of Multinational Firms from Japan and Europe,

Palgrave, Basingstoke etc 
${ }^{1}$ The author gratefully acknowledges comments and suggestions from Peter Katzenstein, Takashi Shiraishi, Miles Kahler, Peter Gourevitch, T.J. Pempel, Derek Hall, Terutomo Ozawa, Mike Hobday, Denis Simon, Norio Tokumaru, Max von Zedtwitz, Richard Baker, Barry Naughton, and Lu Feng.

${ }^{2}$ Data sources include the annual surveys of the Japan Bank for International Cooperation Institute (JBICI) on the Overseas Business Operations of Japanese Manufacturing Companies; annual reports by the Ministry of Economics, Trade \& Industry (METI), JETRO and the Japan Electronics and Information Technology Industries Association (JEITA), the Nomura Research Institute, the Fujitsu Research Institute, the Japan Research Institute, the Japan Electronic Industry Yearbook (Denpa Shinbun, Denshi Kogyo Nenkan), and the Yearbook of World Electronics Data; and specialized newsletters, such as the JETRO China Newsletter, Nomura Research Institute (NRI) Papers, Oxford Analytica, the Interfax China IT \& Telecom Weekly, Electronic Business, Electronics Engineering Times, the Semiconductor Reporter, and CMPnet.Asia.

${ }^{3}$ See Derek Hall's chapter for an analysis of similar developments in renewable resource industries.

${ }^{4}$ Pioneering attempts to establish a unified analysis of FDI and international trade are the technology gap trade theory of Posner (1961) and the international product life cycle theory of Vernon (1966 and 1979). Other scholars have tried to link the theory of foreign direct investment to that of industrial organization of multinational enterprises (e.g., Dunning, 1981, 1993; Ozawa, 2000).

${ }^{5}$ Ministry of Finance date, quoted in JETRO (2002: 25). Note however that MoF data on FDI do not include the quite substantial amounts of reinvestments of Japanese subsidiaries in Asia that do not require a capital transfer from Japan to the region (e.g., Nakagane, 2002:55).

${ }^{6}$ The "overseas production ratio" of a company is defined as (overseas production volume)/ (overseas production volume + domestic production volume) in \% (JBICI 2003, note 8 ).

${ }^{7}$ In 2002, the greatest number of production bases $(1,067)$ was in the ASEAN-4 countries $(+16 \%$ from fy 2000$)$. China is second with 890 Japanese manufacturing affiliates ((+38\% from fy 2000$)$, followed by North America $(752,+17 \%)$, and Asian NIEs $(616,+16 \%)$. This indicates that China has experienced the largest increase in the number of Japanese manufacturing affiliates.

${ }^{8}$ The US "innovation score" measures the number of patents granted by the US Patent Office, multiplied by the socalled "citation index" that indicates the value of these patents The citation index measures the frequency of citation of a particular patent. When the US Patent Office publishes patents, each one includes a list of other patents from which it is derived. The more often a patent is cited, the more likely it is a pioneering patent, connected with 
important inventions and discoveries. An index of more than 1 indicates that patents are cited more often than would be expected for a specific group of technologies, while less than 1 indicates they are cited less often than expected. ${ }^{9}$ With more than $40 \%$ of the overseas sales bases of Japanese manufacturing firms (in fy 2002), East Asia is well ahead of the EU and North America (JBICI, 2003). The number of Japanese sales affiliates in Asia increased by $24 \%$ in the two years from fy 2000 to fy 2002, with the largest increase (+30\%) in China. (Takeuchi 2003: 2). ${ }^{10}$ There are of course huge geographic disparities. Beijing, the Yangtze delta around Shanghai, and the southern coastal provinces have all become leading growth markets, and in some cases even launch markets for digital consumer and mobile communication devices. But beyond these thriving high-end markets, persistent poverty keeps strangulating effective demand.

${ }^{11}$ As Tachiki (1999) shows, it typically takes Japanese firms around three to five years to translate a change in corporate business plans into decisions on the geographic location of resources and to mobilize organizational resources that are necessary to relocate overseas production. This reflects the strictly sequential procedure of corporate decision-making in Japan: only after a systematic restructuring of the corporate business plan has occurred, will management move on to a gradual implementation of changes in overseas operations.

${ }^{12}$ ASEAN-4 includes Malaysia, Thailand, Indonesia and the Philippines, while NIEs covers Singapore, Taiwan and Korea.

13 "Hollowing-out" is defined as a decline in the manufacturing sector's contribution to economic activity (e.g., output or employment) in the home economy in response to increases in FDI outflows.

${ }^{14}$ Yoshihide Ishiyama's interesting study (“Is Japan Hollowing Out?"), published in 1999, was apparently too optimistic. He argues (Ishiyama 1999: 242) that “'hollowing-out' ...should not be a concern for Japan... (as)... Japan's manufacturing industry seems to be much more resilient than that of other countries...After a short while, Japan's manufacturing corporations manage to increase efficiency in producing existing products, upgrade products, or move to new product lines to defend turf against imports and sustain export revenue." Since then, this belief in Japan's invincibility has been thoroughly weakened.

${ }^{15}$ The debate about whether there are differences between Japanese and U.S. FDI has a long history. Over time, the focus of analysis has shifted from trade impacts (e.g., Kojima, 1978, 1986), transfer of technology and the importance of relative factor endowments (Ozawa, 1979; Urata, 1999) to differences in the way in which Japanese and American firms have organized their international business operations, and how these differences affect transaction costs, learning and knowledge diffusion (e.g., Westney, 1999; Fruin, 1997). By the late 1990s, a growing 
literature was addressing these issues for Japanese and American production networks in Asia (e.g., Encarnation, 1995; Hatch and Yamamura, 1996; Ernst and Ravenhill, 2000; Ernst, 1997, 2000). Important differences have been identified in seven areas: geographic dispersion; product mix; localization of management; sourcing of components and capital goods; replication of domestic production networks; impact on trade; and distribution of R\&D activities. ${ }^{16}$ During the early 1980s, when the U.S. dollar appreciated rapidly, cash-strapped American firms were the first to experiment with new forms of international production outsourcing (Ernst, 1997).

${ }^{17}$ Until 1994, the domestic market was reserved for Chinese state-owned enterprises, and virtually closed to foreign companies.

${ }^{18}$ A typical example is Sony's "two-plant policy" that tries to avoid, at almost any cost to be dependent on just one centralized plant for a particular macro-region (Form $20 \mathrm{~F}$ report 2003).

${ }^{19}$ Japanese subsidiaries in China report that, "in order ....not to loose skilled managerial and technical personnel to other companies, we are paying them like we would Japanese employees. We are also giving favorable treatment for transportation and housing" (JBICI, 2003: 39,43).

${ }^{20}$ In the ASEAN region, Japanese firms over the last few years have concentrated primarily on financial consolidation and on the rationalization of supply chains and distribution channels. There have also been attempts to upgrade existing subsidiaries towards flexible mass production of products that, while no longer competitive in Japan, are considered to be too risky to transfer to China because of quality and/or intellectual property protection concerns. Overall however, Japanese FDI in the ASEAN region is unlikely to expand: a "wait-and-see" approach is combined with selective upgrading of some major operations.

${ }^{21}$ Examples of this renewed inflow of Japanese FDI include NEC's decision to shift $70 \%$ of its cell phone production to China; Sanyo's decision to concentrate all air conditioner production in China; Canon's $\$ 80$ million investment in Suzhou, producing copiers; Sony's investments in new notebook production lines; Toshiba's decision to build a very large production line for laptops in Hangzhou, and to transfer a substantial part of its digital TV set production; and Matsushita's \$ 26 million investments in two new plants producing semiconductors for homes appliances.

${ }^{22}$ Import dependence $=$ imports $/($ production-minus exports + imports $)$.

${ }^{23}$ This can have disastrous effects. For instance, Sony’s critically important release of its Playstation 2 game console in China was delayed by an embarrassing miscommunication with the Chinese government. While the Ministry of Culture classifies the PS2 as a gaming machine, Sony registered it as an electronics product, and hence did not get 
the required approval in time for the 2003 Christmas season. It took Sony a few weeks to correct its mistake (Interfax China IT \& Telecom Weekly, 31 January 2004: 3)

${ }^{24}$ For local employees, knowledge of Japanese can be a double-edged sword. On the one hand, it might foster carrier perspectives, even if other skills are missing. On the other hand, however, knowledge of Japanese can also be a disadvantage. These local employees tend to be used as "trouble shooters", and frequently get caught in the middle of conflicts between shop floor workers and senior Japanese managers who often cannot communicate directly. As a result, they find it difficult to concentrate on improving their specialist skills, while at the same time becoming the objects of jealousy from their local co-workers.

${ }^{25}$ Information provided by Dennis Tachiki.

${ }^{26}$ Incidentally, this general manager, P.Y. Lai, used to head Intel's Penang facility in 1992 when I interviewed him in that position, which indicates the breadth of his exposure to leading-edge management practices by global US industry leaders.

${ }^{27}$ The number of Japanese R\&D affiliates in the region covered by the JBICI surveys has increased by $102 \%$ from 39 (in FY 2000) to 79 (in FY 2002). Yet, this compares with 92 R\&D affiliates in North America and 70 in the EU15 (2002). China again has experienced the fastest growth: the number of Japanese R\&D affiliates there increased by $115 \%$ from 13 to 28 .

${ }^{28}$ A unifying theme for current Japanese R\&D strategies that shows up in many annual reports and strategy papers is the concept of "black box" technologies. Matsushita for instance defines them as technologies "that cannot be easily imitated by competitors because they are: (1) protected under intellectual property rights, such as patents, (2) made of complex materials, processes, and know-how that cannot be copied, or (3) made using unique production methods, systems or control technologies. "(Matsusthita Annual Report 2003: 7). And Sharp, one of the most innovative Japanese electronics companies, believes that protecting technologies through patents alone is insufficient, and that the key to success is to maintain exclusive control of manufacturing technologies by "concealing them more assiduously than product technologies" (JETRO, 2003: 44).

${ }^{29}$ For instance, NEC, the leader in R\&D among the nine major Japanese electronics corporations, is a world leader in nanotechnology research, having invented the carbon nanotube that will be the basis for extremely lightweight computer display screens and minute and orders-of-magnitude more efficient semiconductors (Ikezawa, NRI 2003). ${ }^{30}$ While large Taiwanese firms like HonHai, Acer, and Mitac are constrained by government regulations, they have been highly innovative in developing indirect and informal partnerships with Chinese firms. 
31 "Sanyo-Haier Group Alliance Offers Lucrative Foothold”, The Nikkei Weekly, 15 January 2002.

32 “China Alliance Brings Opportunity, Problems", The Yomiui Shimbun, 23 September 2002.

${ }^{33}$ Haier's sales network consists of 42 subsidiaries, 9000 sales locations and almost 12,000 service locations.

${ }^{34}$ In addition to refrigerators, home air conditioners, washing machines and vacuum cleaners, where Haier is the market leader, the company also has moved aggressively into higher-value added digital consumer and communication devices.

35 "Deal Sees Sanyo, Haier as Equals", Asahi Shimbun, 10 January 2002.

${ }^{36}$ Machine-tool orders placed with Japanese firms totaled about Y 790 billion in 2001, down 19\% from a year earlier. As recently as 1997, this figure exceeded Y 1 trillion (METI figures, quoted in "Machine Tools: A Shrinking Domestic Market”, Asahi Shimbun, 6 February 2002).

${ }^{37}$ Toshiaki Iue, president of the Sanyo Haier joint venture and son of Sanyo's CEO, as quoted in "China Alliance Brings Opportunity, Problems", The Yomiui Shimbun, 23 September 2002. 


\section{East-West Center Working Papers: Economics Series}

No. 1 Inter-Organizational Knowledge Outsourcing: What Permits Small Taiwanese Firms to Compete in the Computer Industry?, by Dieter Ernst, May 2000.

No. 2 Catching-Up and Post-Crisis Industrial Upgrading: Searching for New Sources of Growth in Korea's Electronics Industry, by Dieter Ernst, May 2000.

No. 3 Carriers of Cross-Border Knowledge Diffusion: Information Technology and Global Production Networks, by Dieter Ernst, June 2000.

No. 4 IT and the e-Economy: The Ballast for India-U.S. Relations, by Sanjaya Baru, September 2000.

No. 5 Placing the Networks on the Web: Challenges and Opportunities for Managing in Developing Asia, by Dieter Ernst, September 2000.

No. 6 The Impact of Imported and Domestic Technologies on Productivity: Evidence from Indian Manufacturing Firms, by Rana Hasan, September 2000.

No. 7 The Economics of Electronics Industry: Competitive Dynamics and Industrial Organization, by Dieter Ernst, October 2000.

No. 8 Information Technology in the Learning Economy: Challenges for Developing Countries, by Dieter Ernst and Bengt- Åke Lundvall, October 2000.

No. 9 Global Production Networks and the Changing Geography of Innovation Systems: Implications for Developing Countries, by Dieter Ernst, November 2000.

No.10 Moving Beyond the Commodity Trap? Trade Adjustment and Industrial Upgrading in East Asia's Electronics Industry, by Dieter Ernst, January 2001.

No. 11 Trade Relations of Korea and Japan: Moving from Conflict to Cooperation?, by William E. James, January 2001.

No. 12 Knowledge Management: A New Perspective for Development Strategy, by Linsu Kim, January 2001.

No. 13 Understanding Technological Change, by Richard G. Lipsey, February 2001.

No. 14 Inter-Firm Linkages and Development of Capabilities in the Indian Telecom Software Sector, by Rakesh Basant, Pankaj Chandra, and Lynn Mytelka, February 2001.

No. 15 Global Production Networks and Local Capabilities: New Opportunities and Challenges for Taiwan, by Tain-Jy Chen and Shin-Horng Chen, February 2001.

No. 16 Industrial Districts, ICT and Global Production Networks: The Italian Experience, by Paolo Guerrieri, February 2001.

No. 17 E-Commerce and the Semiconductor Industry Value Chain: Implications for Vertical Specialization and Integrated Semiconductor Manufacturers, by David C. Mowery and Jeffrey T. Macher, May 2001.

No. 18 Electronics Contract Manufacturing: Transnational Production Networks, the Internet, and Knowledge Diffusion in Low-Cost Locations in Asia and Eastern Europe, by Boy Luethje, May 2001. 


\section{East-West Center Working Papers: Economics Series}

No. 19 Global Production Networks, Knowledge Diffusion, and Local Capability Formation. A Conceptual Framework, by Dieter Ernst and Linsu Kim, May 2001.

No. 20 The "Hidden" Side of the "flying-Geese" Model of Catch-Up Growth: Japan's Dirigiste Institutional Setup and a Deepening Financial Morass, by Terutomo Ozawa, May 2001.

No. 21 Does Investing in Technology Affect Exports? Evidence from Indian Firms, by Rana Hasan and Mayank Raturi, May 2001.

No. 22 International Economic Integration and Labor Markets in Developing Countries: The Case of Indonesia, by Asep Suryahadi, May 2001.

No. 23 Globalisation, Economic Crisis and Labour Market Policy: Lessons from East Asia, by Chris Manning, May 2001.

No. 24 Trade Policy Reform and Labor Market Dynamics: Issues and an Agenda for Future Research, by Steven J. Matusz, May 2001.

No. 25 Global Production Networks and Industrial Upgrading - A Knowledge-Centered Approach, by Dieter Ernst, May 2001.

No. 26 Globalization and Wage Inequality in Indonesia: A CGE Analysis, by Asep Suryahadi, May 2001.

No. 27 Multinational Corporations and Endogenous Growth: an Eclectic-Paradigmatic Analysis, by Terutomo Ozawa and Sergio Castello, May 2001.

No. 28 The Evolution of a "Digital Economy": Research Issues and Policy Challenges, by Dieter Ernst, July 2001.

No. 29 Trade Liberalization, Labor Markets and Imperfect Competition, by Devashish Mitra, July 2001.

No. 30 The New Mobility of Knowledge: Digital Information Systems and Global Flagship Networks, by Dieter Ernst, July 2001. (See W.P.\# 56 for revised version)

No. 31 Governing Electronic Commerce in a Global Environment, by D. Linda Garcia, August 2001.

No. 32 The Impact of Trade and Labor Market Regulations on Employment and Wages: Evidence from Developing Countries, by Rana Hasan, August 2001.

No. 33 The Internet's Effects on Global Production Networks: Challenges and Opportunities for Managing in Developing Asia, by Dieter Ernst, August 2001.

No. 34 Private Profit or Public Purpose? Corporate Governance Convergence and the Asian State, by James Shinn, September 2001.

No. 35 Implications, Challenges and Prospects for Taiwan in the Knowledge-based Economy, by Tain-Jy Chen, Shin-Horng Chen, and Meng-chun Liu, September 2001.

No. 36 From Digital Divides to Industrial Upgrading. Information and Communication Technology and Asian Economic Development, by Dieter Ernst, October 2001.

No. 37 Transnational Communities and the Evolution of Global Production Networks: The Cases of Taiwan, China and India, by AnnaLee Saxenian, December 2001. 


\section{East-West Center Working Papers: Economics Series}

No. 38 The Impact of Minimum Wage Policy on Wages and Employment in Developing Countries: The Case of Indonesia, by Asep Suryahadi, Wenefrida Widyanti, Daniel Perwira, and Sudarno Sumarto, December 2001.

No. 39 Intellectual Property Rights in China: The Changing Political Economy of Chinese-American Interests, by Sumner La Croix and Denise Eby Konan, January 2002.

No. 40 Knowledge Flows and Industrial Clusters: An Analytical Review of Literature, by Rakash Basant, February 2002.

No. 41 Globalization and Workers in Developing Countries, by Martín Rama, February 2002.

No. 42 National Sovereign Economy, Global Market Economy, and Transnational Corporate Economy, by Dieter Ernst and Terutomo Ozawa, March 2002.

No. 43 Do Global Production Networks and Digital Information Systems make Knowledge Spatially Fluid?, by Dieter Ernst, Jan Fagerberg, and Jarle Hildrum, March 2002.

No. 44 Global Production Networks in East Asia's Electronics Industry and Upgrading Perspectives in Malaysia, by Dieter Ernst, March 2002. [Revised October 2002]

No. 45 Production Networks of Japanese and American Automobile Industry: Contrasting Evolution and Convergence, by Takashi Hayashi, May 2002.

No. 46 Global Production Networks and Information Technology: The Case of Taiwan, by Sing-Horng Chen, May 2002.

No. 47 eBusiness and the Semiconductor Industry Value Chain: Implications for Vertical Specialization and Integrated Semiconductor Manufacturers, by Jeffrey T. Macher, David C. Mowery, and Timothy S. Simcoe, May 2002.

No. 48 Digital Information Systems and Global Flagship Networks: How Mobile is Knowledge in the Global Network Economy, by Dieter Ernst, May 2002.

No. 49 Land Tenure: An Introduction, by Sumner La Croix, June 2002.

No. 50 Trade and Labour Market Linkages in India: Evidence and Issues, by Rayaprolu Nagaraj, August 2002.

No. 51 Multinational Firms and the Evolution of the Indian Software Industry, by Suma S. Athreye, January 2003.

No. 52 R\&D Services and Global Production Networks: A Taiwanese Perspective, by Shin-Horng Chen, Meng-Chun Liu, and Hui-Tzu Shih, March 2003.

No. 53 U.S.-India Technology Cooperation and Capability Building: The Role of Inter-Firm Alliances in Knowledge Based Industries, by Rakesh Basant, March 2003.

No. 54 Globalization and Industrial Labor Markets in South Asia: Some Aspects of Adjustment in a Less Integrated Region, by Krishnarajapet V. Ramaswamy, April 2003.

No. 55 Key Players in the Asia Pacific Oil Market, by Jeffrey Brown and Kang Wu, May 2003.

No. 56 The New Mobility of Knowledge: Digital Information Systems and Global Flagship Networks, by Dieter Ernst, June 2003. 


\section{East-West Center Working Papers: Economics Series}

No. 57 How Sustainable are Benefits from Global Production Networks? Malaysia's Upgrading Prospects in the Electronics Industry, by Dieter Ernst, June 2003.

No. 58 Pathways to Innovation in the Global Network Economy: Asian Upgrading Strategies in the Electronics Industry, by Dieter Ernst, June 2003.

No. 59 Trade Reforms, Labor Regulations and Labor-Demand Elasticities: Empirical Evidence from India, by Rana Hasan, Devashish Mitra, and K.V. Ramaswamy, June 2003.

No. 60 Poverty and Economic Freedom: Evidence from Cross-Country Data, by Rana Hasan, M.G. Quibria, and Yangseon Kim, September 2003.

No. 61 Trade and Workers: Evidence from the Philippines, by Rana Hasan and Lan Chen, September 2003.

No. 62 Pathways to Innovation in Asia's Leading Electronics Exporting Countries - Drivers and Policy Implications, by Dieter Ernst, October 2003.

No. 63. Global Production Networks, Innovation and Work - Why Chip and System Design are Moving to Asia, by Dieter Ernst and Boy Lüthje, October 2003.

No. 64 Internationalisation of Innovation: Why is chip design moving to Asia?, by Dieter Ernst, November 2003.

No. 65 Modularity and the Organization of International Production, by Ari Van Assche, November 2003.

No. 66 Late Innovation Strategies in Asian Electronics Industries: A Conceptual Framework and Illustrative Evidence, by Dieter Ernst. March 2004.

No. 67 Estimation of the J-Curve in China, by Jaleel Admad and Jing Yang. March 2004.

No. 68 Searching for a New Role in East Asian Regionalization - Japanese Production Networks in the Electronics Industry, by Dieter Ernst. March 2004. 